\title{
Hormonal and behavioural patterns in the male camel (Camelus dromedarius)
}

\author{
R. Yagil and Z. Etzion \\ Unit of Comparative Medicine, Faculty of Health Sciences, Ben-Gurion University of the Negev, \\ Beer-Sheva, Israel
}

\begin{abstract}
Summary. Androgen levels in blood and the behaviour of male camels were determined during 1 year. In the months January to April large amounts of androgens were found in blood serum $(\sim 30 \mathrm{ng} / \mathrm{ml}$ compared with $\sim 2 \mathrm{ng} / \mathrm{ml}$ throughout the remaining months) as well as in a secretion from glands on the back of the neck $(36 \mathrm{ng} / \mathrm{ml})$. During this period when hormone levels were high the behaviour of the camels changed: they became unmanageable, blew-out a palatal flap from the mouth, vocalized, and spread urine over their backs with the aid of their tails. The changes in the sexual cycle of the male camels corresponded with the oestrous period in female camels.
\end{abstract}

\section{Introduction}

The female one-humped camel (Camelus dromedarius) has an oestrous period extending from January to April (Volcani, 1952). During this period the females lose their placidity and can become dangerous. During the fertile period the male camels also turn vicious and become unmanageable (Leonard, 1894) and serious injury to man may occur. Like certain other mammals (e.g. deer) the male camel emits a roaring sound in the mating season, i.e. the rut.

However, the question of whether the male one-humped camel is a seasonal breeder has not been satisfactorily answered. A seasonal peak in the weight of the testes (Volcani, 1952; Charnot, 1964) and the numbers of spermatozoa in the epididymis (Volcani, 1952, 1953) were found to correspond with the oestrous period of females. Seasonal breeding of male camels was also suggested by Perk (1962) and Abdel-Raouf, Fatah el Bab \& Owaida (1975), who examined the bulbourethral glands and the morphology of the testes respectively. Other data concerning histochemical observations of the testes (Osman, Moniem \& Tingari, 1976) and studies on the male accessory sex glands (Ali, Moniem \& Tingari, 1976) led to the conclusion that the onehumped camel is not a typical seasonal breeder.

All previous data on the fertility of male camels have been derived from slaughterhouse material and it is possible that the great divergence of opinion could be due to the type of animals that are presented for slaughtering. The usual reasons for slaughtering male camels are sickness, old age or bad behaviour (Schmidt-Nielsen, 1956).

The present work was therefore carried out on healthy male camels to clarify whether the male camel is a seasonal breeder and to obtain a better understanding of the reproductive process in the male camel in general.

\section{Materials and Methods}

Five male camels (Camelus dromedarius) held in the Sinai desert and one male camel held for breeding purposes in the research facility in Beer-Sheva were used in the present project. The 
animals in Sinai (Nos 1-5) were fed a diet consisting of grain and straw and grazed in the immediate area. They were kept in an enclosed area and had no direct contact with females. They could move freely in the enclosed area, but each had his individual territory. The camel in Beer-Sheva (No. 6) was fed a diet of bovine concentrated food and straw. This camel was held in an enclosed yard with 7 females.

Observations of behaviour were made on all the camels but photographs were taken only of Camel 6. Blood was taken from the jugular vein into sterile syringes with no anticoagulating agents. The syringes were placed in crushed ice until centrifugation at $4^{\circ} \mathrm{C}, 173 \mathrm{~g}$ for $15 \mathrm{~min}$. Neck gland secretion was collected by scraping the fluid on the fur directly into a test-tube and was cooled $1 \mathrm{~h}$ later.

All results are given as mean \pm s.d. Significance was determined by paired $t$ tests.

Testosterone concentrations were measured in the serum of all 6 animals and in the neck gland secretion of Camel 6 by a testosterone RIA Kit (Iso-Pac Ltd., Diagnostic Laboratories, Jerusalem, Israel). Results with this kit were identical with the results obtained in the laboratories of the Veterinary Institute at Beith-Dagan (Shemesh \& Hansel, 1974). The antiserum used was raised in sheep to testosterone-3-O-carboxymethyloxine-BSA and had the following crossreactions: $100 \%$ with testosterone, $65 \%$ with $5 \alpha$-dihydrotestosterone, $1-3 \%$ with androstenedione and $<0.01 \%$ with progesterone, cortisol and oestrone. The substance being measured in the camel blood is therefore referred to as androgen rather than testosterone. The labelied ligand $\left(\left[1,2,6,7-{ }^{3} \mathrm{H}\right]\right.$ testosterone) was from the Radiochemical Centre, Amersham, U.K. The standard was from Makor Chemicals, Jerusalem. Extraction was with diethyl ether and incubation was for $20 \mathrm{~min}$ at room temperature. All volumes were $0.1 \mathrm{ml}$ except for the elution buffer $(1 \mathrm{ml})$. Separation was by molecular sieve. The assay blank was the same as the solvent blank. The recovery from serum of $20 \mu \mathrm{l}\left[{ }^{3} \mathrm{H}\right]$ testosterone containing $\sim 1000$ c.p.m. was $89 \pm$ $5 \%$. Radioactivity was determined in a $\beta$-scintillation counter. The sensitivity was $5 \%$ of the Bo value of $55-65 \%=0.1 \mathrm{ng} / \mathrm{ml}$ serum. The intra-assay coefficient of variation was $2.8 \%$.

\section{Results}

\section{Behaviour}

For most of the year the male camels were docile. They were easily manageable and to saddle and ride them presented no problems. In the period between January and April, however, their behaviour underwent a radical change. They became extremely aggressive and were often unapproachable, biting if the chance arose. Removal of blood samples became difficult. No special restraint was used during sampling, but the camels were continually moving and snapping. They roared as the jugular vein was pierced and sometimes the needle and syringe were flung away.

During this period a profuse watery-brown secretion exuded from paired glands situated on the back of the neck just below the ears (Pl. 1, Fig. 2). The secretion from these neck glands began towards the end of October, but only in small amounts and there was no smell. In the period from January to April the secretion had a very strong, foetid odour. If the area of the glands was touched the hands became stained, but this was easily washed off with tap water. The males rubbed their head and neck on every available surface in the immediate area, leaving darkbrown stains.

In the rutting season (January-April), the males periodically extruded a balloon-like organ from the side of the mouth (Pl. 1, Fig. 1). This flabby reddish sac, a palatal flap, was inflated with air that was first stored in the neck area. The protrusion of the balloon was accompanied by a loud gurgling-roaring sound.

Another behavioural pattern, observed only in the rutting season, was the following. The males suddenly spread their back legs and then sharply brushed their tails against the penis, 


\section{PLATE 1}
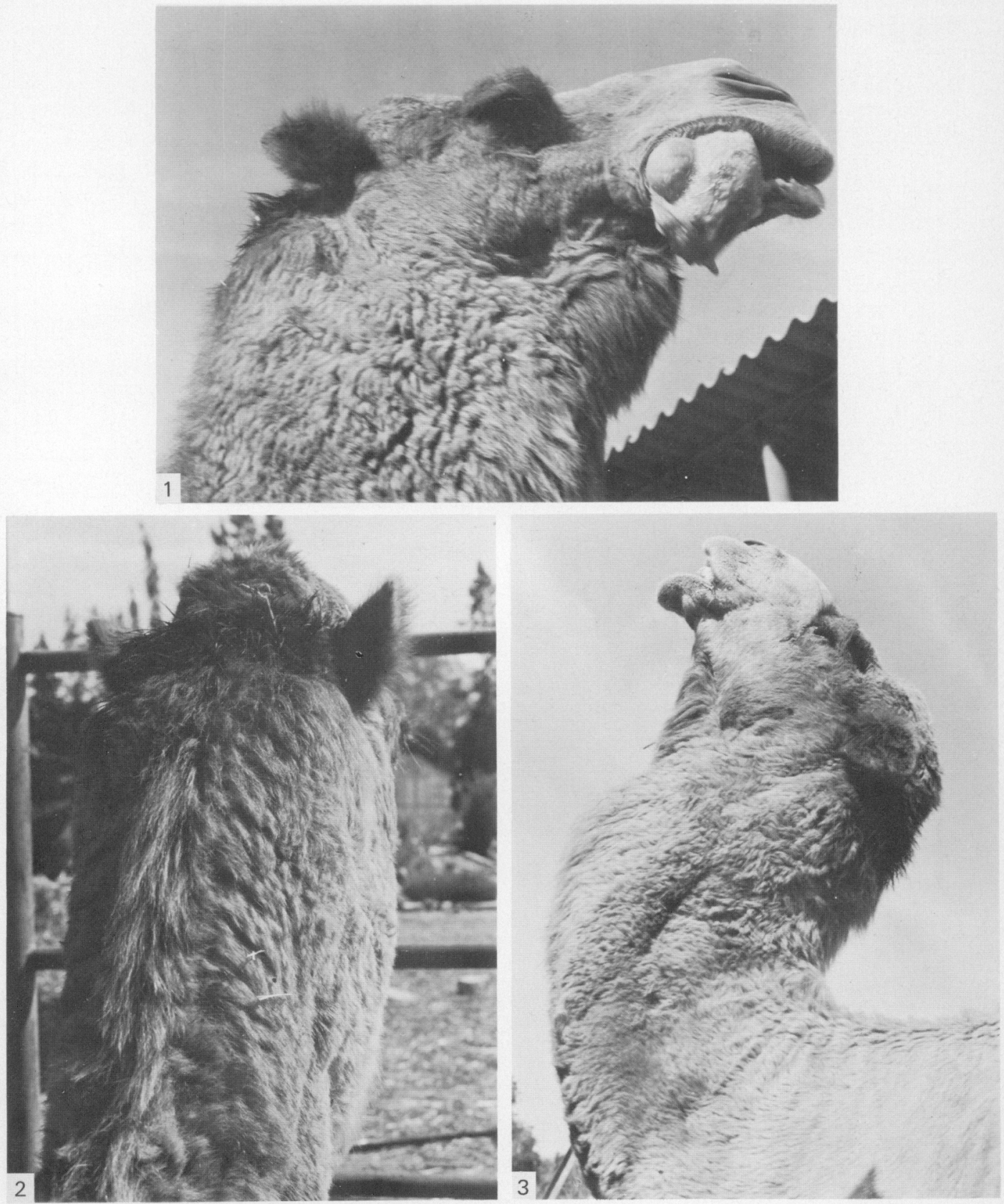

Fig. 1. A male camel in the rutting period showing the extrusion of the palatal sac, which is accompanied by vocalization.

Fig. 2. Photograph of the neck of a male camel in the rutting season, showing the exudation from the neck glands between the ears on the fur.

Fig. 3. A male camel exhibiting Flehmen. 
which is posteriorly directed. After 4 or 5 beats the tail was then held under the urethral opening, a small amount of urine was deposited on the tail and this urine was then swished onto the back. This series of events was repeated 3-5 times/h. After a few days the male's back became caked with a vile-smelling dried crust.

In the rutting period Camel 6 showed a marked interest in female camels. He continually sniffed under their tails and if a female was in oestrus (detected by hormone assay, unpublished) the male stretched his neck up in the air and curled back the upper lip (Flehmen) (Pl. 1, Fig. 3).

\section{Androgen concentrations}

Concentrations of androgens in blood are shown in Table 1. From April until January the androgen values were markedly lower than those found between January and April $(P<0.001)$.

Table 1. Seasonal androgen levels (mean \pm s.d.) in male camels

\begin{tabular}{lcc}
\hline & \multicolumn{2}{c}{ Androgen concentration (ng/ml) } \\
\cline { 2 - 3 } \multicolumn{1}{c}{ Month } & Serum (N=6) & Neck glands (N=1) \\
\hline September & $2 \cdot 3 \pm 1.4$ & 0 \\
October & $1.3 \pm 1 \cdot 1$ & 0 \\
November & $1.8 \pm 0.9$ & 0 \\
December & $17 \pm 3.5$ & 0 \\
January & $33 \pm 4.9$ & 36 \\
February (beginning) & $29 \pm 2 \cdot 8$ & 36 \\
February (end) & $35 \pm 1.5$ & 35 \\
March (beginning) & $29 \pm 1.7$ & 36 \\
March (mid) & $25 \pm 2.8$ & 34 \\
March (end) & $25 \pm 2.1$ & - \\
April & $3.7 \pm 1.2$ & 0 \\
May & $1.5 \pm 1.1$ & 0 \\
June & $1.8 \pm 0.8$ & 0 \\
July & $3.8 \pm 1.6$ & 0 \\
August & $1.4 \pm 0.7$ & 0 \\
\hline
\end{tabular}

Examination of the secretion from the neck-glands of Camel 6 twice a month in the rutting period revealed an androgen concentration of $36 \mathrm{ng} / \mathrm{ml}$. From the end of October, when the secretion started, until January, no androgen activity was found.

\section{Discussion}

The literature to date does not adequately answer the question of whether the male one-humped camel is a seasonal breeder or not. From the present research it is concluded that the male camel is indeed a seasonal breeder, being active between January and April as indicated by hormonal and behavioural changes.

The androgen concentrations in blood were increased more than 10 -fold in the rutting period and were then far higher than those found in bulls, $0.5-2 \mathrm{ng} / \mathrm{ml}$ (Standard-Veterinary Institute, Beith-Dagan) or for man, 4-11 ng/ml (Levine, Diagnostic Labs, Jerusalem). It was clear that the increase in androgens was only found at the time of the oestrous period of the females. Furthermore, increased concentrations of the androgens correlated with radical changes in the behaviour of the male camels. The male camel showed no interest in the females at all during the months when hormone levels were low; only when blood concentrations of the hormones were 
elevated were the males attracted to the females. Following mating the females were inclined to lose interest in the males, but up to mid-April the males still showed great sexual interest in the females. This interest stopped at the same time as blood hormone levels declined. The male then was first in line for food and showed no sexual interest in the females. There was also no secretion from the neck glands or extrusion of the palatal flap when androgen values had fallen to low levels.

Further evidence showing that the substance in the blood and in the secretion from the neck glands is an androgen can be seen from the fact that when slight behavioural changes were found from mid-November to the beginning of December, there was also a slight secretion from the glands and a slight elevation of androgen in blood. Since testosterone is converted to dihydrotestosterone at target organs, it is possible that the hormone in the secretions from the neck glands was actually dihydrotestosterone. The profuse secretion from the glands with high concentrations in hormone levels was only found in the sexually active period. That the secretion from the neck-glands contained large amounts of androgen similar to those in the blood was an unexpected finding. The delay in cooling the neck secretions should not have been a problem because testosterone is stable at room temperature for a few hours (Jainudeen, Katongole \& Short, 1972).

The behaviour of the male camels was directly correlated with the changes in secretion of androgen. The various manifestations in behaviour seen in the rutting period can be ascribed to two causes: either direct attraction of the females or delineation of territory from other males. The blowing-out of the palatal flap and the spraying of urine over the back are probably done to attract the females. The females can be seen smelling the male's crusted back and from afar react to the noise when the palatal flap is extruded. The marking of the surroundings by the odoriferous secretion from the neck glands is probably connected with territorial delineation. In Sinai during the rutting season a male camel wandering into the marked territory of another was immediately attacked, while the attacker did not leave his own immediate area to attack any other camel. He in turn was attacked when he encroached on another's territory, even if the other camel was weaker.

A great similarity can be seen between the data for the male camel (Camelus dromedarius) and those for the Asiatic elephant (Jainudeen et al., 1972). The Asiatic elephant (Elephas maximus) also has its period of sexual activity, the musth, mainly between the months of January and April. In this period the plasma testosterone levels were also high, reaching 65.4 $\mathrm{ng} / \mathrm{ml}$, values much higher than those found in the camels. As with the camels in rut, the elephant in musth becomes aggressive and unmanageable. The elephant too, plays with his penis; he beats it against his belly and also dribbles urine. Elephants also exude a secretion from the temporal glands on the head during the sexual period, but the secretion has not been assayed for hormone content.

The present results confirm those of others, although no data concerning actual testicular activity are presented. Seasonal changes in weight of testes (Charnot, 1964; Volcani, 1952, 1953) suggest a direct correlation with sexual activity, but one peak in weight of testes and epididymis was found in February-March, in the rutting period, while another peak was found in August-October. In the one-humped camel thyroid metabolism was higher in the heat of summer than in winter (Yagil, Etzion \& Ganani, 1978) and it has been shown in bulls that the state of the seminiferous tubules is reflected by thyroid activity (Volcani, 1954).

Although the weight of the testis was correlated with the mating season there were signs that spermatogenesis was present throughout the year (Charnot, 1964). If this was the case in the camels examined in the present study, there was no effect on hormone levels in blood and the males were not sexually aroused. That the enzymes and chemical components of the testes (Osman et al., 1976) and histochemical studies of the accessory sex glands (Ali et al., 1976) were not affected by the season tends to contradict the theory of seasonal breeding. The apparent discrepancy between the data concerning examinations of testes or accessory sex 
glands are difficult to explain. It is possible that climatic conditions as well as age, health and disposition of the animals from which the specimens were obtained played a major role. Aggression in the males leads to the abattoir (Schmidt-Nielsen, 1956) and it is most probable that aggression is due to testosterone secretion. In this present communication data were collected from live healthy animals that were examined for a year. It is clear that the occurrence of the rutting period in winter has the advantages of negating the problems of water deprivation, food shortage or heat.

This research was supported by a grant No. M.G.21 from the Israel Commission for Basic Research. We express our gratitude to the Camel Corps of the Israel Defence Forces for lending one of their camels for the year and for allowing us to take blood from the camels in the desert. We are grateful to Mr Goel Drori for the photographs.

\section{References}

Abdel-Raouf, M. F., Fatah el Bab, M.R. \& Owaida, M. M. (1975) Studies on reproduction in the camel (Camelus dromedarius). V. Morphology of the testis in relation to age and season. J. Reprod. Fert. 43, 109-116.

Ali, H.A., Moniem, K.A. \& Tingari, M.D. (1976) Some histochemical studies on the prostate, urethral and bulbourethral glands of the one-humped camel. Histochem.J. 8, 565-578.

Charnot, Y. (1964) Le cycle testiculaire du dromedaire. Bull. Soc. Sci. nat. phys. Maroc. 44, 37-45.

Jainudeen, M.R., Katongole, C.B. \& Short, R.V. (1972) Plasma testosterone levels in relation to musth and sexual activity in the male Asiatic elephant, Elephas maximus. J. Reprod. Fert. 29, 99-103.

Leonard, A.G. (1894) The Camel. Longmans Green, London.

Osman, D.I., Moniem, K.A. \& Tingari, M.D. (1976) Studies on the testis of the camel (Camelus dromedarius). III. Histochemical observations. Histochem.J. 8, 579-590.

Perk, K. (1962) Seasonal changes in the bulbourethralis of the camel. Bull. Res. Council. Israel 10E, 37-44.
Schmidt-Nielsen, K. (1956) Animals and arid conditions: physical aspects of productivity and management. In The Future of Arid Lands, pp. 368-382. Am. Ass. for Advancement of Science, Washington D.C.

Shemesh, M. \& Hansel, W. (1974) Measurement of bovine plasma testosterone by radio-immunoassay (RIA) and rapid competitive protein binding (CPB) assay. J. Anim. Sci. 39, 720-724.

Volcani, R. (1952) Seasonal activity of gonads and thyroidea in camel, cattle, sheep and goats. Ph.D. thesis, Hebrew University, Jerusalem.

Volcani, R. (1953) Seasonal variations in spermatogenesis of some farm animals under the climatic conditions of Israel. Bull. Res. Council. Israel 3, 123-126.

Volcani, R. (1954) Seasonal changes in sperm production in some farm animals in the Israeli climate. Refuah Vet. 11, 40.

Yagil, R., Etzion, Z. \& Ganani, J. (1978) Camel thyroid metabolism: effect of season and dehydration. $J$. appl. Physiol. 45, 540-544.

Received 5 March 1979 